\title{
Sarcopenia, nutritional status and functionality in elderly women living in the community
}

Rosa Sá de Oliveira Neta' Isabelle Ferreira da Silva Souza' Saionara Maria Aires da Câmara' Marcelo Cardoso de Souza'

\section{Abstract}

Objective: to evaluate the relationship between sarcopenia, functional capacity and nutritional status among elderly women living in the community. Method: an observational, cross-sectional study was performed with 100 elderly women aged over 60 years. A questionnaire containing identification and socioeconomic data and information relating to the practice of physical activity was applied, while anthropometric and body composition data were measured through bioimpedance and functionality data was assessed using the six-minute walk test (6MWT). Independent t-tests were performed for the quantitative variables and analysis of variance (ANOVA) was used to compare the means of the variables. Multiple linear regression analyzes were performed to estimate the mean 6MWTfor each of the variables studied. Results: The average age of the elderly women was $67( \pm 8.0)$ years, $41 \%$ practiced physical activity, 38\% had at least an elementary school education, $48 \%$ received up to two minimum wages and $91 \%$ were obese according to waist circumference (WC). The prevalence rates for the presence of sarcopenia were: $5 \%$ for sarcopenic obesity (SO), 63\% for obesity, 14\% for sarcopenia and $18 \%$ had adequate weight. Elderly women who practiced physical activity, had at least an elementary education and who were non-obese according to WC, performed better in the 6MWT. There were no significant differences in the 6MWTbased on income or Body Mass Index ( $p>0.05$ ). Non-obese and non-sarcopenic women walked further in the functional test than the other women $(\mathrm{p}=0.021)$. Conclusion: SO was present in $5 \%$ of the elderly women and is related to poor physical performance, which was also present in elderly women with sarcopenia and obesity.

\footnotetext{
Universidade Federal do Rio Grande do Norte, Faculdade de Ciências da Saúde do Trairi, Programa de Pós-graduação em Saúde Coletiva. Santa Cruz, Rio Grande do Norte, Brasil.
}

\section{Keywords: Aging.}

Nutritional Assessment.

Walking Test. Sarcopenia. 


\section{INTRODUCTION}

The Brazilian National Health Policy of the Elderly (PNSPI) states that the main problem affecting elderly persons is the loss of functionality. This is due to the progression of illnesses resulting from the greater probability of exposure to chronic noncommunicable diseases $(\mathrm{CNCD})^{1}$.

Some of the changes to the body characteristic of aging are the loss of lean mass and skeletal muscle function, which can be associated with functional limitation, disability and even mortality. This agerelated muscular atrophy is called sarcopenia ${ }^{2}$. This implies a disturbance in the balance between the synthesis of the muscle proteins and the destruction of these proteins, which is the main contributor to the etiology of sarcopenia. Sarcopenia is multifactorial disease, and includes nutritional, metabolic and hormonal factors ${ }^{2}$.

The investigation of conditions that impair functionality is important, as changes in body composition can cause limitations in the physical condition of the individual and lower functional performance ${ }^{3}$. However, there is a lack of studies that evaluate the presence of sarcopenia and the functional deficit and nutritional status of elderly women living in the community in municipal regions in the north east of Brazil.

Based on the foregoing, the assessment of these conditions in elderly women in the municipality of Santa Cruz (Rio Grande do Norte), Brazil, is important, as in keeping with a national trend in Brazil there is a progressive increase of women over 60 years of age with inadequate nutritional status due to obesity in this region ${ }^{5}$. The objective of the present study was to evaluate the relationship between sarcopenia and the functional capacity and nutritional status of the elderly resident in the community.

\section{METHOD}

This is an epidemiological, observational crosssectional, analytical study with a quantitative approach. A total of 100 elderly women over 60 years old registered with the Physiotherapy Clinical School of the Trairi Faculty of Health Sciences of the Universidade Federal do Rio Grande do Norte
(FACISA-UFRN) were selected. This is a public service for physiotherapeutic treatment, frequented by socioeconomically vulnerable individuals, and serves residents of the Trairi region and adjacent towns. The period of data collection occurred between September and December 2016, in the municipality of Santa Cruz, Rio Grande do Norte.

Only women were evaluated for this study, because although changes in muscle mass (MM) are common in both sexes, the decrease in strengthassociated MM does not occur in the same proportion for both genders over time. A study has suggested there is a rapid loss of strength in women aged 50 and over, while in men this reduction does not begin until at least the age of $60^{6}$.

Inclusion criteria for the study were: women aged 60 years or over who understood the guidelines of the procedures performed, who could walk independently, with or without assistance devices, and who did not have arthroplasty, amputated lower limbs, rheumatologic diseases (chikungunya, for example) or use a pacemaker, because of possible interference with the bioimpedance (BIA) test. The inability to perform any of the procedures of the research protocol was considered to be an exclusion criterion.

The study complied with Resolution $n^{\circ}$ 466/2012 of the National Health Council which regulates research involving human beings, and was submitted to and approved by the Ethics Research Committee of FACISA-UFRN, under approval number 1.707.598/2016.

Participants were recruited through telephone contact from the patient lists of the clinic. Data collection was performed through the application of a questionnaire standardized by two nutritionists, who were previously trained so that there was no disagreement between the data collected. The instrument was duly validated in a pilot study. This questionnaire was applied in a single sitting and contained information regarding identification, health aspects, quality of life, socioeconomic data, family history, anthropometric data and body composition and functionality. The elderly were evaluated for demographic and socioeconomic data such as age, schooling and family income. The practice of physical activity was self-reported and 
defined as the practice of physical activity at least three times a week, with at least thirty minutes for each session.

Weight and height were measured using techniques recommended by the World Health Organization $(\mathrm{WHO})^{7}$. Weight was measured with the individual barefoot and wearing light clothes, using a WELMY ${ }^{\circledR}$ electronic scale (capacity of $150 \mathrm{~kg}$ and accuracy of 100 grams). Height was measured with the WELMY® stadiometer (accuracy of $0.5 \mathrm{~cm}$ ) with the individual barefoot and in the orthostatic position.

These data were obtained for the calculation of body mass index (BMI), which is an index defined by the measurement of weight expressed in $\mathrm{kg}$, divided by height expressed in meters squared (BMI= weight/ height ${ }^{2}$ ). The BMI was calculated using the following classification cut-off points: malnutrition (BMI $<22$ $\left.\mathrm{kg} / \mathrm{m}^{2}\right)$, normal weight $\left(\right.$ BMI $=22 \mathrm{~kg} / \mathrm{m}^{2}$ and $<27$ $\left.\mathrm{kg} / \mathrm{m}^{2}\right)$ and obesity $\left(\mathrm{BMI} \geq 27 \mathrm{~kg} / \mathrm{m}^{2}\right)$, which were proposed by Lipchitz ${ }^{8}$.

Measurements of the body perimeters were measured with the aid of a $150 \mathrm{~cm}$ SANNY® flexible and non-elastic anthropometric scale. Waist circumference (WC) was measured at the midpoint between the last rib and the iliac crest for classification of the risk of metabolic complications associated with obesity. The WHO cut-off points for women ${ }^{7}$, which consider moderate risk to be WC between $80 \mathrm{~cm}$ and $88 \mathrm{~cm}$ and high risk $\geq 88$ $\mathrm{cm}$, were used. BMI is an effective indicator but does not fully correlate with body fat, as it does not define its distribution. It also does not distinguish fat mass from lean mass, and may be less accurate in older individuals, due to the loss of lean mass and weight loss, being overestimated in individuals with high lean mass.

The evaluation of body composition was made by BIA analysis, performed with a portable HBF$514 \mathrm{c}$ body mass analyzer. This is an easy-to-use, reproducible, non-invasive, relatively inexpensive and confirmed valid method?

For the application of the BIA the elderly women were asked to avoid the use of diuretic medication the day before the exam; not perform physical activity for at least 12 hours preceding the test; urinate prior to the test; not drink alcohol or caffeine drinks; remove jewelry or items containing metal from the body and fast from food and water for at least four hours before the test.

The elderly were placed on the scale platform with electrodes on their feet and instructed to place their hands on the horizontal rod with other electrodes attached, and then to hold the device with their arms extended forwards, forming a $90^{\circ}$ angle with the trunk, with both hands over the electrodes, so that the electric current could travel through the upper limbs and upper trunk region. During the test, which lasts on average 30 seconds, the elderly women were instructed not to move or talk and to maintain an upright posture.

Functionality was evaluated through the application of the six-minute walk test (6MWT), which is a field test that consists of instructing the evaluated individual to walk as far as possible for six minutes in a space of 30 meters, with marks on the ground every three meters; at the end of the course, the patient should walk around a cone that delimits the space and change direction ${ }^{10}$. The distance traveled was calculated through the Enright and Sherrill equations and then classified in accordance with the same authors, who consider that healthy people walk around 400 to 700 meters in 12 minutes $^{11}$.

Elderly persons with $\mathrm{WC} \geq 88 \mathrm{~cm}$ were considered obese, as proposed by the Brazilian obesity guidelines defined by the Brazilian Association for the Study of Obesity and Metabolic Syndrome? ${ }^{9}$. These guidelines suggest that $\mathrm{WC}$ is more sensitive than BMI in obesity screening.

The elderly were classified as sarcopenic when the measured MM provided by the BIA was below the $20^{\text {th }}$ percentile of the study sample $(<6.22 \mathrm{~kg} /$ $\left.\mathrm{m}^{2}\right)^{6}$. Sarcopenic obesity (SO) was classified with the concomitant presence of obesity and sarcopenia. The elderly were therefore classified into four groups: sarcopenic, obese, obese and sarcopenic and adequate, which was composed of non-obese and non-sarcopenic elderly women.

A descriptive statistical analysis of the population data was performed. The normality of the data was verified by the Kolmogorov-Smirnov test. For the categorical variables (practice of physical activity, schooling 
and income) analysis of variance (ANOVA) was used. In order to compare the means of the variables: physical activity, schooling, income, BMI, WC and the four $6 \mathrm{MWT}$ classification groups, the independent t-tests and ANOVA were used. Finally, multiple linear regression analyzes were performed by the backward method to estimate the mean 6MWT for each of the variables studied, adjusting for potential confounding factors or covariates, such as practice of physical activity, age and schooling. Confounding factors were identified according to the literature and bivariate analysis.

\section{RESULTS}

The socioeconomic characteristics, body composition and physical activity practice of the sample can be seen in Table 1. Initially, the sample included 105 elderly women, but five were excluded due to their inability to carry out the tests. The final sample consisted of 100 elderly women with a mean age of $67( \pm 8.0)$ years.

The distribution of the elderly women into the four classification groups can be seen in Table 2 .

Table 1. Characterization of socioeconomic factors, body composition and practice of physical activity of the elderly (N=100). Santa Cruz, Rio Grande do Norte, 2017.

\begin{tabular}{ll}
\hline Variable & Mean (standard-deviation) \\
\hline Age & $67,0( \pm 8.0)$ \\
\hline Physical activity & $\mathrm{n}(\%)$ \\
Yes & $41(41)$ \\
No & $59(59)$ \\
Schooling & \\
Illiterate & $20(20)$ \\
Elementary School & $38(38)$ \\
High school & $32(32)$ \\
Higher education & $10(10)$ \\
\hline Income (minimum salary) & \\
Up to 2 & $48(48)$ \\
$2-4$ & $(22)$ \\
$>4$ & $30(30)$ \\
\hline Body mass index $\left(\mathrm{kg} / \mathrm{m}^{2}\right)$ & \\
$<27 \mathrm{~kg} / \mathrm{m}^{2}$ (non-obese) & $26(26)$ \\
$\geq 27 \mathrm{~kg} / \mathrm{m}^{2}$ (obese) & $74(74)$ \\
Waist circumference $(\mathrm{cm})$ & \\
$<88 \mathrm{~cm}$ (non-obese) & $9(9)$ \\
$\geq 88 \mathrm{~cm}$ (obese) & $91(91)$ \\
\hline
\end{tabular}

Table 2. Classification of elderly women in terms of presence of sarcopenia, obesity and sarcopenic obesity (N=100). Santa Cruz, Rio Grande do Norte, 2017.

\begin{tabular}{ll}
\hline Classification & $\mathrm{n}(\%)$ \\
\hline Adequate & $18(18)$ \\
Sarcopenia & $14(14)$ \\
Obesity & $63(63)$ \\
Sarcopenic obesity & $5(5)$ \\
\hline
\end{tabular}


It was found that elderly women who practiced physical activity walked an average of $374.73 \mathrm{~m}$, while those who did not practice such activities covered $318.75 \mathrm{~m}(\mathrm{p}=0.007)$. In relation to schooling, those who were illiterate walked between $288.88 \mathrm{~m}$ and $337.18 \mathrm{~m} ; 369.20 \mathrm{~m}$ and $369.63 \mathrm{~m}$ were walked by those who had an elementary school education, a from elementary to secondary level education, and a higher than secondary level education, respectively $(p=0.045)$. Elderly women who received up to two minimum wages walked $322.78 \mathrm{~m}$, those who received between four and four minimum wages $373.18 \mathrm{~m}$, and those who received more than four wages $356.73 \mathrm{~m}(p=0.101)$.
Table 3 shows $6 \mathrm{MWT}$ performance according to the variables of body composition and distribution in the four classification groups.

The multiple linear regression analysis for the 6MWT in relation to the variables of body composition adjusted by the covariables age, physical activity and schooling can be seen in Table 4 .

Multiple linear regression analysis for the 6MWT was also performed in relation to the classification groups adjusted for the covariables age, physical activity and schooling (Table 5). Statistically significant differences in 6MWT were found between the groups $(p<0.05)$.

Table 3. Six-minute walk test (6MWT) results according to body composition variables and classification groups. Santa Cruz, Rio Grande do Norte, 2017.

\begin{tabular}{llc}
\hline Variable & Mean and standard-deviation & $p$-value \\
\hline Body mass index $\left(\mathrm{kg} / \mathrm{m}^{2}\right)$ & $363.71( \pm 96.03)$ & 0.081 \\
$<27 \mathrm{~kg} / \mathrm{m}^{2}$ (non-obese) & $321.50( \pm 105.53)$ & \\
$\geq 27 \mathrm{~kg} / \mathrm{m}^{2}$ (obese) & & \\
Waist circumference $(\mathrm{cm})$ & $399.33( \pm 63.82)$ & $0.041^{*}$ \\
$<88 \mathrm{~cm}$ (non-obese) & $336.39( \pm 104.33)$ & \\
$\geq 88 \mathrm{~cm}$ (obese) & & $0.021^{*}$ \\
Classification in groups & $376.28( \pm 78.73)$ & \\
Adequate & $351.14( \pm 110.04)$ & \\
Sarcopenia & $333.40( \pm 107.70)$ & \\
Obesity & $280.00( \pm 34.64)$ & \\
Sarcopenic obesity &
\end{tabular}

Table 4. Multiple linear regression analysis for the six-minute walk test (6MWT) in relation to body composition measurements. Santa Cruz, Rio Grande do Norte, 2017.

\begin{tabular}{lllc}
\hline Variable & \multicolumn{2}{l}{ 6MWT (meters) } & \\
\hline Model 1* & $\beta$ & CI 95\% & \\
Body malue** index & & & 0.236 \\
$<27 \mathrm{~kg} / \mathrm{m} 2$ (non-obese) & 28.10 & $-18.74-74.96$ & \\
$\geq 27 \mathrm{~kg} / \mathrm{m}^{2}$ (obese) & 0 & & \\
\hline $\begin{array}{l}\text { Model 2* } \\
\text { Waist circumference }\end{array}$ & & & 0.096 \\
$<88 \mathrm{~cm}$ (non-obese) & 56.74 & $-10.25-23.74$ & \\
$\geq 88 \mathrm{~cm}$ (obese) & 0 & & \\
\hline
\end{tabular}

*Models adjusted by the variables age, schooling and physical activity; ${ }^{* *}$ statistical significance $(p<0.05)$ in linear regression. 
Table 5. Multiple linear regression analysis for the six minute walk test (6MWT) in relation to classification groups. Santa Cruz, Rio Grande do Norte, 2017.

\begin{tabular}{llll}
\hline Variable & 6MWT (meters) & & \\
\hline Model $1^{*}$ & B & CI 95\% & $p$-value** \\
Adequate & 59.64 & $-62.61-181.89$ & $0.006^{* *}$ \\
Sarcopenia & 37.34 & $-87.83-162.52$ & \\
Obesity & 24.63 & $-89.54-138.813$ & \\
Sarcopenic obesity & 0 & & \\
\hline
\end{tabular}

*Model adjusted by the variables age, schooling and physical activity; **statistically significant $(p<0.05)$ in linear regression.

\section{DISCUSSION}

Sarcopenia and SO are considered to be challenges to public health as they are significant causes of frailty among the elderly. Little is known, however, about their relationship with the functional capacity of this population ${ }^{2}$. In the present study, the performance of sarcopenic women in the $6 \mathrm{MWT}$ was inferior to that of non-obese and nonsarcopenic elderly women $(p=0.021)$, in contrast to the findings of Gadelha et al. ${ }^{12}$ and Lima et al. ${ }^{13}$ who verified that the performance of the elderly women with sarcopenia, although inferior, did not present a significant association with functional tests. These results indicate that the reduced MM of elderly individuals requires attention and should be maintained at adequate levels, leading to better functional capacity and helping to promote the autonomy of this population.

It is therefore necessary for health services to act in a preventive manner, both to diagnose and reduce risk factors for the loss of lean mass and functionality, as well as to provide guidance about the changes caused by aging or even to rehabilitate those already affected by these deficits. By adopting an expanded approach to care, health services can help not only the elderly, but also their families, to adopt healthy living habits so that they can reduce these changes and their consequences, contributing to the access to and the attainment of a quality of life by overcoming disabilities and age-related limitations. It is therefore possible to increase the ways that the elderly deal with aging, by formulating guidelines for a health policy that introduces new knowledge and practices to healthcare teams, and includes professionals in nutrition and physical therapy ${ }^{14}$.
A prevalence of sarcopenia of $14 \%$ was found in the present study. It is difficult to compare prevalence among Brazilian and non-Brazilian populations due to the lack of well-defined cut-off points. The value of MM was lower than $6.22 \mathrm{~kg} / \mathrm{m}^{2}$, corroborating the cut-off points found in literature by Santos et al. ${ }^{15}$ and Hofmann et al. ${ }^{16}$, which were $<5.45 \mathrm{~kg} / \mathrm{m}^{2}$ and $\leq 6.75 \mathrm{~kg} / \mathrm{m}^{2}$, respectively, in populations similar to the present study.

The lack of uniformity in the identification of these conditions makes it difficult to identify their relationship with functionality. The European Consensus on the definition and diagnosis of sarcopenia ${ }^{17}$ also recognizes the importance of muscle quality in the diagnosis of sarcopenia and $\mathrm{SO}$, as the infiltration of fat into the muscle tissue can cause a reduction in functional performance. Therefore, while it is important to consider variables such as body mass, muscle strength and physical performance in this diagnosis, the methods of identification require future studies that contemplate such factors ${ }^{17}$.

The prevalence of sarcopenia in our study was similar to that of the study by Santos et al. ${ }^{15}$ which obtained results of $16.8 \%$ with 149 elderly women, with a mean age $67.17( \pm 6.12)$ years. Du et al. ${ }^{18}$ evaluated the prevalence of sarcopenia in 2,458 volunteers over 65 years of age from different racial/ethnic groups and obtained results similar to the present study in white women, with a prevalence of sarcopenia of $15.1 \%$, while in black women the prevalence was only $1.6 \%$.

In the present study, the majority of the population had an education up to elementary school $(38 \%)$ and received up to two minimum 
wages $(48 \%)$. Such individuals had an inferior 6MWT performance than those with higher levels of education and better socioeconomic status. The amount of MM can be influenced by factors such as age, height, body weight, ethnicity/skin color, and also by nutrition and the amount of time spent exposed to socioeconomic adversity ${ }^{18}$.

The study by Machado and Vieira ${ }^{19}$ found that socioeconomic adversities such as a lack of schooling influenced the functionality of the elderly, as those who were illiterate had a 2.61-times greater chance of dependency in instrumental activities of daily living than those who were literate. Schooling allows the elderly to develop skills that facilitate the resolution of health problems and contribute to avoiding or delaying such issues.

It is consistent to assume that the poorer socioeconomic status, lower level of schooling, and miscegenation commonly found in the Brazilian population may in part explain poorer performance in the 6MWT, which may be explained by the inappropriate use of equations from other countries to estimate the distance traveled in the 6MWT in the population of the present study. In a study with Norwegians, the distance walked in the 6MWT was $132 \mathrm{~m}$ greater in those with better schooling and $30 \mathrm{~m}$ in those with better socioeconomic status ${ }^{20}$.

SO was relatively frequent and associated with poor performance in the 6MWT. While the prevalence of $\mathrm{SO}$ in the present study was $5 \%$, other studies have found higher prevalences, such as that of Moreira ${ }^{6}$, which had a prevalence of $7.1 \%$ in middle-aged women in northeastern Brazil and that of Monteiro et al. ${ }^{21}$ with post-menopausal women, which had a prevalence of $9.2 \%$. Oliveira et al. ${ }^{22}$ found a prevalence of $\mathrm{SO}$ of $19.8 \%$ in elderly women with a mean age of $66.8( \pm 5.6)$ years, which was associated with reduced muscle strength and functional deficit. The same was reported by Gadelha et al. ${ }^{12}$, with a prevalence of $23.4 \%$.

The practice of physical activity has as a protective effect on the development of sarcopenia and $\mathrm{SO}$, as it helps to maintain or even increase MM and strength, reduce body fat and obesity and, consequently, improve motor performance ${ }^{23,24}$. However, 59\% of our sample were elderly women who practiced physical activity less than three times a week, and had a worse performance in the 6MWT $(\mathrm{p}<0.05)$. A similar result was found by Santos et al. ${ }^{25}$ who found that insufficient physical activity was associated with sarcopenia or SO in 770 individuals aged 50 years or older in the southeastern part of Brazil.

Other authors did not find significant correlations between 6MWT and the scores of a questionnaire on daily activity ${ }^{26}$ and self-reported physical activities, including habitual walking and regular physical activity $^{20}$. Although physical activity is positively associated with the maintenance of functionality, reducing the deleterious effects of aging ${ }^{27}$, specific studies on the influence of physical activities on 6MWT are still needed.

Calculations of obesity detecting possible health risks are often based on BMI, which depicts only one change in the individual's energy balance. It does not, however, allow other factors, such as metabolic and inflammatory disorders and MM/ body mass, to be considered ${ }^{28}$.

In the present study, a prevalence of obesity of $91 \%$ was found, based on WC. In the National Survey on Health and Nutrition (PNSN) of 1989, approximately half $(50.2 \%)$ of the elderly women evaluated were overweight, based on $\mathrm{BMI}^{29}$. The Telephone Surveillance System for Risks and Preventive Factors for Chronic Diseases (VIGITEL) identified prevalence rates of $53.4 \%$ in 2006 and $58.5 \%$ in $2012^{30}$.

The results of linear regression analysis shown in Table 5 reveal that elderly women who were only obese had a worse 6MWT performance than elderly women with sarcopenia or who were non-obese and non-sarcopenic $(\beta=24.63$; $\mathrm{CI}=89.54-138.81$, $p=0.006)$. It is believed that a high BMI limits $6 \mathrm{MWT}$ performance, as obesity can influence gait and increase workload ${ }^{31}$. In our study, there was no significant difference between obese and nonobese individuals according to $\mathrm{BMI}$ in the $6 \mathrm{MWT}$ $(p=0.081)$. Camarri et al. ${ }^{26}$ corroborated these results when evaluating the 6MWT in 70 Caucasian adults suggesting that, optionally, other anthropometric variables, such as WC, can be used.

As an alternative to the classification of obesity, WC was assessed in the present study, and the elderly women who presented central obesity (WC $\geq 88 \mathrm{~cm}$ ) 
also had worse functional performance, walking significantly less than those without central obesity. One of the explanatory hypotheses proposed by the study of Campanha-Versiani et al. ${ }^{32}$, which evaluated the performance of 48 elderly women with WC $>88 \mathrm{~cm}$ and found a similar result to the study under discussion, is that the deposition of visceral fat could influence energy expenditure in the exercise, considering that there are also greater obstacles in walking for obese individuals.

The results obtained show the importance of using different forms of obesity diagnosis (BMI and WC) in the diagnosis of sarcopenia and SO, as highlighted in the study by Souza et al. ${ }^{32}$, to identify elderly obesity in individual and collective evaluations, aimed at a more accurate prognosis of health problems through these parameters of adiposity. Health professionals should therefore look beyond BMI, which alone is not sufficient to assess premature risk, as it fails to classify a considerable portion of the population at imminent cardiometabolic risk $^{33}$.

One limitation of this study is its transversal design, which did not allow a temporal relationship of cause and effect to be established among the variables. Another is the sample projection which, in addition to working with a small sample to determine prevalence, only allowed the investigation of the inadequacy of functional capacity of elderly women who attended FACISA/ UFRN. The lack of a heterogeneous sample meant the present data could not be extrapolated.

\section{CONCLUSION}

Obesity was a highly prevalent condition among the elderly women in the study, with sarcopenia and sarcopenic obesity less frequent conditions in this sample. However, although obesity and sarcopenia were significantly associated with a significantly worse performance on the six-minute walk test, the combination of the two conditions (obesity and sarcopenia) resulted in even worse outcomes than the two conditions separately.

Based on the increase in the disability rates which accompany growing population aging, the results of the present study demonstrate the need to investigate the presence of both conditions among elderly populations, in order to identify those with a higher probability of experiencing changes in functional performance. With this, it will be possible to guide appropriate prevention and rehabilitation strategies, aimed at reducing the functional dependency levels in this population.

\section{REFERENCES}

1. Brasil. Portaria GM n 2.528 , de 19 de outubro de 2006. Aprova a Política Nacional de Saúde da Pessoa Idosa- PNSI. Diário Oficial da União. 20 out. 2006. p. 142.

2. Shlisky J, Bloom DE, Beaudreault AR, Tucker KL, Keller HH, Freund-Levi Y, et al. Nutritional considerations for healthy aging and rReduction in age-related chronic disease American Society for Nutrition. Adv Nutr. 2017;8(1):17-26.

3. Stenholm S, Alley D, BandinellI S, Griswold ME, Koskinen S, Rantanen T, et al. The effect of obesity combined with low muscle strength on decline in mobility in older persons: results from the In CHIANTI study. Int J Obes. 2009;33(1):635-44.
4. Instituto Brasileiro de Geografia e Estatística. Censo demográfico 2010: Resultados da amostra características da população - 2010 [Internet]. Rio de janeiro: IBGE; 2010 [acesso em 07 jul. 2017]. Disponível em: http:/cidades.ibge.gov.br/xtras/ temas.php?lang $=\&$ codmun $=241120 \&$ idtema $=90$ $\&$ search $=$ rio-grande-do-norte $\mid$ santa-cruz $\mid$ censodemografico-2010:-resultados-da-amostracaracteristicas-da-populacao-

5. Ribeiro AA, Pessoa MTG, Azevedo SMU, Oliveira VTL, Meireles AL. Caracterização socioeconômica, estado nutricional e prevalência de insegurança alimentar em idosos usuários do restaurante popular de um município do nordeste brasileiro. Rev Ciênc Plur. 2016;2(3):212-8. 
6. Moreira MA. Envelhecimento e qualidade de vida pra idosos: um estudo de representações sociais [tese]. Natal: Universidade Federal do Rio Grande do Norte, Centro de Ciências da Saúde; 2016.

7. Organização Mundial de Saúde. Physical status: the use and Organization. [Sem Local]: WHO; 1995.

8. Lipschitz DA. Screening for nutritional status in the elderly. Prim Care. 1994;21(1):1994.

9. Associação Brasileira para o Estudo da Obesidade e da Síndrome Metabólica. Diretrizes Brasileiras de Obesidade 2016 [Internet]. $4^{a}$ ed. São Paulo; 2016 [acesso em 10 nov. 2017]. Disponível em: http://www.abeso.org.br/uploads/ downloads/92/57fccc403e5da.pdf

10. Hill K, Dolmage TE, Woon L, Coutts D, Goldstein $\mathrm{R}$, Brooks D. Defining the relationship between average daily energy expenditure and field-based walking tests and aerobic reserve in COPD. Chest. 2012;141(2):406-12.

11. Enright PL, Sherril DL. Reference equations for the six-minute walk in healthy adults. Am J Respir Crit Care Med. 1998;158(5):1384-7.

12. Gadelha AB, Dutra MT, Oliveira RJ, Safons MP, Lima RM. Associação entre força, sarcopenia e obesidade sarcopênica com o desempenho funcional de idosas. Motricidade. 2014;10(3):31-9.

13. Lima ARS, Portes LA, Oliveira NC, Alfieri FM. Limiar de tolerância de dor à pressão, estilo de vida, força muscular e capacidade funcional em idosas com sarcopenia. Acta Fisiatrica. 2016;23(2):212-20.

14. Aciole GG, Batista LH. Promoção da saúde e prevenção de incapacidades funcionais dos idosos na estratégia de saúde da família: a contribuição da fisioterapia. Saúde Debate. 2013;37(96):10-9.

15. Santos RR, Bicalho MAC, Mota P, Oliveira DR, Nunes E. Obesity in the elderly. Rev Med Minas Gerais. 2013;22(6):499-511.

16. Hofmann M, Halper B, Oesen S, Franzke B, Stuparits $\mathrm{P}$, Tschan H. Serum concentrations of insulinlike growth factor-1, members of the TGF-beta superfamily and follistatin do not reflect different stages of dynapenia and sarcopenia in elderly women. Exp Gerontol. 2015;64(6):35-45.

17. Cruz-jentoft AJ, Baeyens JP, Bauer JM, Boirie Y, Cederholm T, Landi F, et al. Sarcopenia: European consensus on definition and diagnosis: report of the European working group on sarcopenia in older people. Age Ageing. 2010;39(4):412-23.
18. Du K, Goates S, Arensberg MB, Pereira S, Gaillard T, Hegazi R. Ethnic variations in the prevalence of sarcopenia and sarcopenic obesity in older adults. FASEB J. 2017;31(11):1-2.

19. Machado A, Vieira MCU. Impacto de fatores socioeconômicos na funcionalidade da pessoa idosa portadora de condições crônicas. Rev Enferm UFSM. 2015;5(1):81-91.

20. Saad B, Prefaut C, Tabka Z, Mtir AH, Chemit M, Hassaoune R, et al. 6-minute walk distance in healthy North Africans older than 40 years: influence of parity. Respir Med. 2009;103(1):74-84.

21. Monteiro MA, Gabriel RC, Sousa MF, Castro $\mathrm{MN}$, Moreira MH. Temporal parameters of the foot roll-over during walking: influence of obesity and sarcopenic obesity on postmenopausal women. Maturitas. 2010;67(2):178-85.

22. Oliveira LPBA, Medeiros LMF, Meirelles BHS, Santos SMA. Satisfação da população idosa atendida na estratégia de saúde da família de Santa Cruz, Rio Grande do Norte. Texto \& Contexto Enferm. 2011;23(4):871-9.

23. Atkins JL, Whincup PH, Morris RW, Lennon LT, Papacosta O, Wannamethee SG. Sarcopenic obesity and risk of cardiovascular disease and mortality: A population-based cohort study of older men. J Am Geriatr Soc. 2014;62(2):253-60.

24. Bann D, Kuh D, Wills AK, Adams J, Brage S, Cooper R. Physical activity across adulthood in relation to fat and lean body mass in early old age: findings from the medical research council national survey of health and development, 1946-2010. Am J Epidemiol. 2014;179(10):1197-207.

25. Santos VR, Araujo MYC, Cardoso MR, Batista VC, Christofaro DGD, Gobbo LA. Association of insufficient physical activity with sarcopenia and sarcopenic obesity in individuals aged 50 years or more. Rev Nutr. 2017;30(2):175-84.

26. Camarri B, Eastwood PR, Cecins NM, Thompson PJ, Jenkins S. Six minute walk distance in healthy subjects aged 55-75 years. Respir Med. 2006;100(4):658-65.

27. Organização Mundial de Saúde. Envelhecimento ativo: uma política de saúde. Brasília, DF: OPAS; 2005.

28. Leone C, Nascimento VG, Silva JPC, Bertoli CJ. Razão cintura/estatura: marcador de alteração nutricional em pré-escolares. Rev Bras Crescimento Desenvolv Hum. 2014;24(3):289-94.

29. Instituto Nacional de Alimentação e Nutrição. Pesquisa Nacional sobre Saúde e NutriçãoPNSN.1989. Arquivo de dados da pesquisa. Brasília, DF: MS; 1991. 
30. Malta DC, Andrade SC, Claro RM, Bernal RTI, Monteiro CA. Evolução anual da prevalência de excesso de peso e obesidade em adultos nas capitais dos 26 estados brasileiros e não Distrito Federal entre 2006 e 2012. Rev Bras Epidemiol. 2014;17:267-76.

31. Gomes-Neto M, Araujo, AD, Junqueira IDA, Oliveira D, Brasileiro A, Arcanjo FL. Estudo comparativo da capacidade funcional e qualidade de vida entre idosos com osteoartrite de joelho obesos e não obesos. Rev Bras Reumatol. 2016;56(2):126-30.
32. Campanha-versiani L, Silveira ECBR, Pimenta, MC, Alvarenga SG, Parentoni AN, Ribeiro-Samori GA, et al. Influência da circunferência abdominal sobre o desempenho funcional de idosas. Fisioter Pesqui. 2010;17(4):327-31.

33. Souza IFS, Oliveira Neta RS, Gazzola JM, Souza MC. Idosos com osteoartrite de joelhos devem realizar avaliação nutricional: revisão integrativa da

Received: November 18, 2017

Reviewed: March 14, 2018

Accepted: May 25, 2018 